\title{
A review of opioid prescription in a teaching hospital in Colombia [Corrigendum]
}

Moyano J, Figueras A. J Pain Res. 2012;5:237-242.

Jairo Moyano is also affiliated with Deparment de Farmacologia, Terapeutica i Toxicologia, Universitat Autonoma de Barcelona, Barcelona, Spain, which was not included in the original publication.

\section{Publish your work in this journal}

The Journal of Pain Research is an international, peer-reviewed, open access, online journal that welcomes laboratory and clinical findings in the fields of pain research and the prevention and managemen of pain. Original research, reviews, symposium reports, hypothesis formation and commentaries are all considered for publication.
The manuscript management system is completely online and includes a very quick and fair peer-review system, which is all easy to use. Visit http://www.dovepress.com/testimonials.php to read real quotes from published authors. 